\title{
HUBUNGAN TEKANAN DARAH TINGGI DENGAN KEJADIAN STUNTING PADA ANAK
}

\author{
Wahyu Widyaningsih ${ }^{1}$, Intan Permata Dewi ${ }^{2}$
}

\author{
${ }^{1}$ Dosen Prodi Kebidanan Politeknik Kudus \\ Email : aleenaahza@gmail.com \\ ${ }^{2}$ Dosen Prodi Kebidanan Politeknik Kudus \\ Email : intan33_permata@yahoo.com
}

\section{ABSTRACT: THE RELATIONSHIP OF HIGH BLOOD PRESSURE WITH STUNTING IN CHILDREN}

Introduction: Reducing stunting in children is the most important goal of the six goals of the Global Nutrition Targets 2025 and a key indicator in the second Sustainable Development Goal of No Hunger. The prevalence of child stunting in Indonesia has remained high over the last decade, and at the national level it is around $37 \%$. It is unclear whether the current approach to reducing child stunting is in line with the World Health Organization's conceptual framework on child stunting to review the available literature and identify what has been learned and can be concluded about the determinants of child stunting in Indonesia and where data gaps still exist. Community and community factorsin particular, poor access to health care and living in rural areas-have been repeatedly linked to stunted children. Published studies are lacking on how education is; society and culture; agriculture and food systems; and water, sanitation and the environment contribute to child stunting.

Purpose: the purpose of the study is to analyze the relationship of high blood pressure with stunting in children.

Method: This study uses an observational research with a case control study design and uses a retrospective approach conducted on children with an age range of 5-14 years. The population of this study was 210 children aged 5-14 years, the number of samples in this study was 192 consisting of 64 case samples and 128 control samples.

Result: The results showed 64 respondents who were stunted and 128 who did not experience stunting. And the results showed that most infants and toddlers who were stunted had no hypertension status in their mothers during pregnancy as much as $43,51 \%$ and $56,49 \%$ in infants and toddlers who were not stunted with their mothers during pregnancy.

Conclusion: There is a relationship between high blood pressure and the incidence of stunting in children.

Keywords:stunting; hypertension;kid's healty. 


\section{INTISARI: HUBUNGAN TEKANAN DARAH TINGGI DENGAN KEJADIAN STUNTING PADA ANAK}

Pendahuluan: Pengurangan stunting pada anak merupakan tujuan terpenting dari enam tujuan Global Nutrition Targets 2025 dan indikator kunci dalam Sustainable Development Goal of No Hunger kedua. Prevalensi stunting anak di Indonesia tetap tinggi selama dekade terakhir, dan di tingkat nasional sekitar $37 \%$. Tidak jelas apakah pendekatan saat ini untuk mengurangi pengerdilan anak sejalan dengan kerangka konseptual Organisasi Kesehatan Dunia tentang pengerdilan anak untuk meninjau literatur yang tersedia dan mengidentifikasi apa yang telah dipelajari dan dapat disimpulkan tentang determinan pengerdilan anak di Indonesia dan di mana kesenjangan data masih ada. Faktor masyarakat dan masyarakat-khususnya, akses yang buruk ke perawatan kesehatan dan tinggal di daerah pedesaan-telah berulang kali dikaitkan dengan anak-anak yang terhambat. Studi yang diterbitkan kurang tentang bagaimana pendidikan itu; masyarakat dan budaya; sistem pertanian dan pangan; dan air, sanitasi, dan lingkungan berkontribusi terhadap pengerdilan anak.

Tujuan penelitian: penelitian ini bertujuan untuk menganalisa hubungan antara tekanan darah tinggi dan stunting pada anak.

Metode Penelitian: penelitian ini menggunakan jenis penelitian observasional dengan rancangan studi case control dan menggunakan pendekatan retrospektif yang dilakukan pada anak dengan rentang umur 5-14 tahun. Populasi dari penelitian ini adalah 210 anak usia rentang 5-14 tahun jumlah sampel dalam penelitian ini adalah 192 yang terdiri dari jumlah sampel kasus 64 dan jumlah sampel kontrol 128.

Hasil: Hasilnya menunjukkan64 responden yang mengalami stunting dan 128 yang tidak mengalami stunting. Dan didapatkan hasil sebagian besar bayi dan balita yang stunting memiliki status hipertensi pada ibunya saat hamil sebanyak 43,51\% dan pada bayi serta balita yang stunting memiliki status tidak hipertensi pada ibunya saat hamil sebanyak $56,49 \%$.

Kesimpulan: ada hubungan antara tekanan darah tinggi dengan kejadian stunting anak.

Kata kunci: stunting; tekanan darah tinggi; kesehatan anak

\section{PENDAHULUAN}

Usia sekolah merupakan masa khusus dimana anak bertumbuh dan berkembang, dengan demikian proses tersebut harus dilengkapi dengan mematuhi berbagai aturan kesehatan. Periode ini sangat penting karena anak-anak akan memperoleh pengetahuan, membangun sikap, dan mengembangkan perilaku yang berhubungan dengan kesehatan terutama di sekolah. Selama periode ini, langkah-langkah perlindungan dan promosi kesehatan harus dilakukan dan penentuan awal masalah kemungkinan akan terjadi mencegah/menunda pembelajaran dan akan mencegah masalah lebih lanjut terjadi di masa depan atau akan memberikan kesempatan untuk mengatasi masalah tersebut dengan mudah (Ergun, Erol, Gur, \& Isman, 2016). Pelayanan yang akan diberikan kepada anak usia sekolah antara lain pemeriksaan kesehatan pada saat pendaftaran untuk sekolah; pemeriksaan fisik berkala; pemantauan tumbuh kembang; dan pemeriksaan penglihatan, pendengaran, gigi, dan skoliosis 
(Nihiser, Lee, Wechsler, McKenna, Odom, \& Reinold, 2007).

Memantau tumbuh kembang anak sangat penting untuk dilakukan dengan seimbang terutama dilakukan dalam pelayanan kesehatan sekolah. Pengukuran tinggi-berat badan tahunan adalah metode yang sederhana namun efektif dalam deteksi dini masalah kesehatan yang serius, seperti usus, endokrin, dan investigasi untuk melihat apakah ada penyakit bawaan (Ergun, Erol, Gur, \& Isman, 2016). Dalam lingkup Pemantauan Proyek Pertumbuhan Anak Usia Sekolah (kelompok usia 6-10 tahun) di Turki, pengukuran antropometri dari 11.387 anak-anak di bidang pedesaan dan perkotaan dari 26 provinsi mengungkapkan bahwa 6,5\% obesitas, $14,3 \%$ kelebihan berat badan, $1,3 \%$ sangat kurus, 5,0\% terhambat, dan 21,5\% pendek.

$$
\text { Di Eropa, Prevalensi }
$$

kelebihan berat badan dan obesitas tertinggi pada anak-anak berada di Spanyol (35,2\% di antara anak usia 69 tahun) dan Portugal $(31,5 \%$ di antara anak usia 7-9 tahun), sedangkan prevalensi terendah Slovakia (15\% di antara anak berusia 7-9 tahun), Prancis $(18,1 \%$ di antara 7-9 tahun), Swiss (18,3\% di antara 69 tahun), dan Islandia $(18,5 \%$ di antara anak usia 9 tahun) (Branca, Nikogosian, \& Lobstain, 2007). Menurut temuan klinis, meskipun hipertensi pada masa kanak-kanak masih jarang ditemukan daripada hipertensi dewasa, perkembangan hipertensi esensial pada orang dewasa dimulai dalam 10 menit pertama dalam setahun kehidupan, dan anak-anak yang memiliki riwayat keluarga hipertensi lebih rentan terhadap hipertensi. Dengan demikian, mendeteksi hipertensi harus dimulai sejak masa kanakkanak (Kilic, Basibuyuk, Tekin, Nalir, \& Olak, 1995). Tekanan darah dalam anak-anak dinilai menggunakan kurva persentil berdasarkan usia, jenis kelamin, dan berat badan, dan tiga pengukuran berturut-turut harus dipertimbangkan (Evaluasi, Diagnosa danPengobatan Tekanan Darah Tinggi Pada Anak Dan Remaja, 2005) Dalam sebuah penelitian di Kanada, korelasi positif yang tinggi ditentukan antara obesitas dan tekanan darah sistolik pada sekitar 2000 anak dan remaja berusia 6-17 tahun. Tekanan darah pada remaja obesitas ditentukan menjadi 7,6 $\mathrm{mmHg}$ lebih tinggi secara rata-rata. Sedangkan prevalensi hipertensi adalah $<1 \%$, prevalensi prehipertensi sekitar 2,2\% (Shi, Groh, \& Morrison, 2012). Dalam sebuah penelitian yang dilakukan di Tunisia, hipertensi terdeteksi pada 4,7\% remaja (Aonallah, et al., 2012). Perbedaan regional dalam prevalensi hipertensi anak berasal dari banyak faktor, seperti: sebagai praktik budaya yang berbeda, kebiasaan diet, faktor lingkungan, metode pengukuran, dan perbedaan usia (Discigil, Aydogdu, Basak, Gemalmaz, \& Gurel, 2007). Bagian kesehatan sekolah bekerja sama dengan administrasi sekolah juga berperan penting untuk membantu mengidentifikasi risiko kesehatan lebih awal, merencanakan intervensi yang tepat, dan untuk mengambil tindakan yang diperlukan. Dengan demikian, mereka berkontribusi tidak hanya untuk perlindungan kesehatan anak tetapi juga untuk kelanjutan integritas keluarga dan penggunaan yang tepat dari sumber daya masyarakat dengan diagnosis dini (Ergun, Erol, Gur, \& Isman, 2016).

Salah satu gangguan tumbuh kembang anak adalah stunting yangdialami anak akibat gizi buruk, infeksi berulang, dan stimulasi psikososial yang tidak memadai. Anak-anak didefinisikan sebagai stunting jika tinggi badan menurut usia mereka lebih dari dua standar 
deviasi di bawah median Standar Pertumbuhan Anak WHO. Stunting pada awal kehidupan - terutama pada 1000 hari pertama sejak pembuahan sampai usia dua tahun gangguan pertumbuhan memiliki konsekuensi fungsional yang merugikan pada anak. Beberapa dari konsekuensi tersebut termasuk kognisi yang buruk dan kinerja pendidikan, upah orang dewasa yang rendah, kehilangan produktivitas dan, bila disertai dengan penambahan berat badan yang berlebihan di masa kanak-kanak, peningkatan risiko penyakit kronis terkait gizi di masa dewasa.

Pertumbuhan linier pada anak usia dini merupakan penanda kuat pertumbuhan yang sehat mengingat hubungannya dengan risiko morbiditas dan mortalitas, penyakit tidak menular di kemudian hari, dan kapasitas belajar dan produktivitas. Hal ini juga terkait erat dengan perkembangan anak dalam beberapa domain termasuk kapasitas kognitif, bahasa dan sensorik-motorik. Selama dekade terakhir di Indonesia, hanya ada sedikit perubahan dalam prevalensi nasional stunting anak, yaitu sekitar $37 \%$. Ada disparitas yang besar secara subnasional, berdasarkan provinsi dari 26\% di Kepulauan Riau menjadi 52\% di Nusa Tenggara Timur (Yuce, 2007).

Ini menunjukkan variasi paparan populasi terhadap faktorfaktor penentu stunting pada anak dan kebutuhan untuk menargetkan dan menyesuaikan intervensi untuk yang paling rentan. Ada banyak potensi penyebab stunting di Indonesia, termasuk faktor-faktor terdekat seperti status gizi ibu, praktik menyusui, praktik pemberian makanan pendamping, dan paparan infeksi serta determinan distal terkait seperti pendidikan, sistem pangan, perawatan kesehatan, dan infrastruktur air dan sanitasi dan tentunya hipertensi. Penelitian ini bertujuan untuk mengevaluasi prevalensi masalah stunting dan hubungannya dengan hipertensi pada siswa berusia 5-14 tahun.

\section{METODE}

Penelitian ini menggunakan jenis penelitian observasional dengan rancangan studi case control dan menggunakan pendekatan retrospektif yang dilakukan pada anak dengan rentang umur 5-14 tahun. Populasi dari penelitian ini adalah 210 anak usia rentang 5-14 tahun jumlah sampel dalam penelitian ini adalah 192 yang terdiri dari jumlah sampel kasus 64 dan jumlah sampel kontrol 128 Besar sampel kasus dan kontrol dalam penelitian ini menggunakan perbandingan 1:2. Peneliti melakukan penyeleksian terhadap sample dengan menggunakan teknik purposive sampling. Data usia dan jenis kelamin siswa dicatat dalam formulir.Kemudian, hasilnya dicatat dalam lembar data. Jika seorang siswa memilikimasalah kesehatan, guru kelas, konselor sekolah, dankeluarga diberitahu, dan siswa dirujuk ke dokter. Selain itu, peneliti juga melakukan pengambilan data sebagai berikut:

1) Pengukuran Tinggi: Sebelum pengukuran, siswa perempuandiminta untuk melepas jepit rambut. Pita pengukur dipasang kedinding yang datar. Pengukuran dilakukan sesuai denganstandar pengukuran tinggi badan. Hasilnya dicatat dalamsentimeter (Pekcan, Penentuan Status Gizi Diet Handbook, 2008a) (Pekcan, Penetapan Status Gizi Seri Informasi Gizi Pelayanan Kesehatan Dasar Managemen Umum Kementrian Kesehatan Republik Turki, 2008b) Tinggi 
badan untuk usia diklasifikasikan sebagai kerdil $(<-2$ standar deviasi [SD]), pendek $(\geq-2$ SD $-<-1$ SD), normal ( $\geq-1 S D-<+1$ SD), tinggi $(\geq+1 \quad S D<+2 \quad S D)$, dan sangat tinggi $(\geq+2 \mathrm{SD})$

2) Pengukuran Berat:Timbangan dengan sensitivitas $100 \mathrm{~g}$ telah dipakai. Timbangan dikalibrasi sebelum setiap pengukuran. Saat mengukur berat badan, siswa mengenakan seragam sekolah yang tipis, melepas sepatu, dan tidak menyentuh di mana pun (Pekcan, Penentuan Status Gizi Diet Handbook, 2008a)\& (Pekcan, Penetapan Status Gizi Seri Informasi Gizi Pelayanan Kesehatan Dasar Managemen Umum Kementrian Kesehatan Republik Turki, 2008b). Bobot untuk usia dievaluasi sesuai dengan penilaian Zscore yang direkomendasikan oleh Organisasi Kesehatan Dunia (WHO) diklasifikasikan sebagai sangat kurus (<2 SD), kurus $(\geq-2$ SD $<-1$ SD), normal $(\geq-1$ SD $-<1$ SD), kelebihan berat badan $(\geq+1$ SD $-<+2 S D)$, dan obesitas ( $\geq+2$ SD) (12). Hasilnya dicatat dalam kilogram (kg).

3) Pengukuran Tekanan Darah: Saat anak beristirahat sekitar 15 menit, dia diberitahu bagaimana tekanan darahnya diukur. Semua pengukuran dilakukan pada lengan kanan. Digunakan sebuah manset yang sesuai untuk lingkar lengan anak-anak. Manset ditempatkan tepat di atas antecubitalfossa untuk menutupi dua pertiga dari panjang lengan atas. Diafragma stetoskop ditempatkan sedikit di atas brakialisarteri, manset dipompa hingga tekanan 20 $\mathrm{mmHg}$ dimana tekanan nadi brakialis hilang, dan kemudian tekanan berkurang dengan kecepatan 2-3 mm $\mathrm{Hg} /$ detik (SIAPA, 2007b). Tekanan darah yang diukur adalah diklasifikasikan sebagai normal $(<90 \quad \mathrm{P})$, prehipertensi (90 $\mathrm{P}-<95 \mathrm{P})$, stadium-Ihipertensi (95 P-99 P), dan hipertensi stadium II (>99 P) (Tumer, et al., 1999).

Kemudian data akan dianalisis secara statistic dimana data dianalisis menggunakan paket perangkat lunak Statistical Package for Social Sciences (SPSS) 20.0 (IBM Corp.; Armonk, NY, USA).Untuk menganalisis data, angka, distribusi persentase, aritmatikaberarti, dan SD digunakan. Untuk perbandingan statistik, analisis chisquare digunakan. Parameter antropometri diukur menggunakan nilai referensi WHO-2007 (Yuce, 2007).

\section{HASIL DAN PEMBAHASAN}

Kekurangan gizi merupakan masalah kesehatan global, konsekuensi yang sangat jelas dalamnegara berkembang di mana 32\% anak-anak di bawah 5 tahun (178 juta bayi) terhambat. Seorang perwakilan penelitian yang dilakukan di Brasil telah menunjukkan bahwa prevalensi stunting pada anak-anak dan remaja berusia antara10 dan 19 tahun bervariasi menurut kelas ekonomi. Dengan demikian, sedangkan 22,1\% pria dengan penghasilan bulanan hingga satu seperempat dari gaji minimum terhambat, hanya $5,9 \%$ dari mereka yang memiliki penghasilan bulanan lebih dari lima minimum gaji menderita dari efek stunting. Penyebab utama stunting termasuk perawatan prenatal yang buruk, penambahan berat badan selama kehamilan, penyapihan 
prematur atau makanan tambahan yang tidak memadai, tingkat pendidikan yang rendah.

Beberapa studi epidemiologi telah menunjukkan bahwa anakanak yang telah menderita defisit pertumbuhan selama intrauterine periode atau di awal kehidupan cenderung memiliki risiko lebih tinggi untuk berkembang penyakit tidak menular hipertensi di masa dewasa4-6. Selain itu, risiko seperti itu tampaknya tergantung pada kondisi lingkungan di mana individu hidup7-9. Menurut penelitian terbaru tentang anak-anak dan remaja dengan stunting gizi, penurunan linear pertumbuhan selama masa kanak-kanak meningkatkan kerentanan terhadap Obesitas (Yuce, 2007) dan hipertensi (Pekcan, Penentuan Status Gizi Diet Handbook, 2008a). melaporkan bahwa prevalensi rata-rata hipertensi di kalangan remaja status sosial ekonomi rendah dan stunting adalah $21 \%$ dan, dalam kelompok ini, prevalensi darah sistolik atau diastolik tekanan (SBP dan DBP, masing-masing) di atas persentil ke90 (disesuaikan dengan tinggi badan) adalah 51\%. Sebuah studi di Brazil yang melibatkan orang dewasa dari daerah miskin (SIAPA, 2007b). Mengungkapkan bahwa asosiasi antara pengerdilan dan hipertensi lebih kuat pada wanita $(38,5 \%)$ dibandingkan pada pria $(18,4 \%)$, dan bahwa prevalensi hipertensi di antara wanita kerdil obesitas adalah $50 \%$.

\section{Hasil Analisis Distribusi Frekuensi Kesehatan}

Tabel 1. Distribusi Frekuensi

Status HDK, Status Anemia, Status Risiko KEK Dan Tinggi Badan

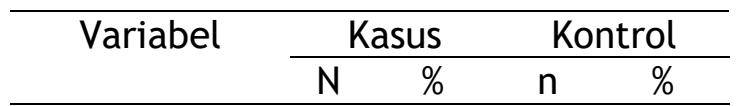

\begin{tabular}{|c|c|c|c|c|}
\hline \\
\hline $\begin{array}{ll}\text { Status HDK } \\
-\quad \text { Hipertensi } \\
-\quad & \text { Tidak } \\
& \text { Hipertensi }\end{array}$ & $\begin{array}{l}29 \\
35\end{array}$ & $\begin{array}{l}43,51 \\
56,49\end{array}$ & $\begin{array}{c}22 \\
106\end{array}$ & $\begin{array}{l}17,91 \\
81,83\end{array}$ \\
\hline \multicolumn{5}{|l|}{ Tinggi Badan } \\
\hline$-\quad<150$ & 37 & 51,87 & 10 & 7,18 \\
\hline$-\quad>150$ & 27 & 49,21 & 118 & 91,29 \\
\hline \multicolumn{5}{|c|}{ Status risiko KEK } \\
\hline - Risiko KEK & 31 & 44,48 & 38 & 26,69 \\
\hline Tidak & 33 & 56,51 & 90 & 71,30 \\
\hline Risiko KEK & & & & \\
\hline \multicolumn{5}{|c|}{ Status Anemia } \\
\hline Anemia & 50 & 78,21 & 66 & 56,51 \\
\hline Tidak & 14 & 28,17 & 62 & 47,84 \\
\hline Anemia & & & & \\
\hline
\end{tabular}

Berdasarkan tabel diatas didapatkan hasil penelitian 64 responden yang mengalami stunting dan 128 yang tidak mengalami stunting. Dan didapatkan hasil sebagian besar anak yang stunting memiliki status tidak hipertensi pada ibunya saat hamil sebanyak 56,49\% dan pada anak yang tidak stunting memiliki status tidak hipertensi pada ibunya saat hamil sebanyak $81,83 \%$. Sebagian besar anak yang stunting karena merupakan keturunan dari Ibu.

Hasil analisis pengaruh status HDK terhadap kejadian stunting di peroleh bahwa pada kasus ibunya saat hamil memiliki status Hipertensi sebanyak $43,51 \%$ dan pada kontrol ibunya saat hamil memiliki status Hipertensi sebanyak 17,91\%. Hasil uji statistik diperoleh nilai $p=0,001$ maka dapat disimpulkan bahwa kasus dan kontrol ada pengaruh status hipertensi terhadap kejadian stunting, dari hasil analisi diperoleh pula nilai $O R=4,967$ yang mempunyai arti bayi dan balita yang ibunya mempunyai status hipertensi saat hamil berisiko 4,967 kali lipat untuk terjadinya stunting. Hasil analisis pengaruh status anemia terhadap kejadian stunting (Sari, et al., 2010). Berdasarkan hasil analisis statistik menunjukkan ada hubungan antara tekanan darah tinggi dengan 
kejadian stunting anak. Hal ini dibuktikan dengan data pada tabel 2 diatas.

Dalam studi tersebut, hasil pada stunting, parameter lain dari pertumbuhan dan perkembangan, dievaluasi. Ketika anak diklasifikasikan menurut tinggi untuk skor Z, ditentukan bahwa $1,1 \%$ terhambat dan 5,9\% pendek. Ketika distribusi tinggi untuk usia Skor Z dianalisis pada kelompok usia 12 tahun, tingkat anak perempuan yang kerdil dan pendek lebih tinggi dari tingkat anak laki-laki dengan tinggi yang sama; namun, anak laki-laki yang sangat tinggi lebih tinggi dari tingkat anak perempuan dengan tinggi yang sama $(p=0,006)$. Menurut Childhood Obesity Survey (2013), angka anak stunting parah adalah $0,1 \%$, dan angka anak stunting adalah 2,3\%.

Menurut hasil ANOVA 2 arah untuk SBP, interaksi adalah signifikan $(p=0,01)$ artinya bertubuh 2 kelompok menyajikan pola perilaku yang berbeda terkait dengan BMI klasifikasi (Gambar 1). Bahkan, dalam kelompok agak kerdil, Nilai SBP individu yang kelebihan berat badan secara signifikan lebih tinggi $(p=0,02)$ dibandingkan individu dengan berat badan normal $(114,70 \pm 15,46$ dan $104,72 \pm 12,24 \mathrm{mmHg}$, masingmasing) sedangkan dalam kelompok perawakan normal, tidak ada perbedaan yang signifikan antara nilai SBP individu kelebihan berat badan dan normal $(109,39 \pm 10,93$ dan 109,45 $\pm 15,03 \mathrm{mmHg}$, masingmasing).

Sehubungan dengan tekanan darah diastolik, kelebihan berat badan ringan kelompok kerdil menunjukkan peningkatan yang signifikan dibandingkan dengan kelompok stunting ringan kurus $(69,75 \pm 12,03 \mathrm{mmHg}$ dan $54,46 \pm$ $11,24 \mathrm{mmHg}, p=0,01$, masingmasing), serupa ke IMT normal
$(62,44 \pm 9,42 \mathrm{mmHg}, \mathrm{p}=0,15)$. Dalam keadaan normal kelompok perawakan, individu yang kelebihan berat badan menunjukkan nilai yang sama dari DBP $(67,42 \pm 10,30 \mathrm{mmHg})$ dibandingkan dengan berat badan kurang dan IMT normal $(56,11 \pm$ $13,89 \mathrm{mmHg}, \mathrm{p}=0,46 ; 63,16 \pm 12,76$ $\mathrm{mmHg}, \quad \mathrm{p}=0,11$, masing-masing). Beberapa faktor yang diketahui terkait dengan hipertensi pada orang dewasa juga telah dikaitkan dengan peningkatan tekanan darah pada masa kanak-kanak dan remaja (Agca \& Koncoglu, 2010).

Diantara faktor lingkungan yang berhubungan dengan fisiopatologi hipertensi, kelebihan berat badan telah diakui sebagai penentu elemen tidak hanya pada orang dewasa tetapi juga pada anak-anak. Lebihlebih lagi, pengerdilan diyakini terkait dengan peningkatan darah pressure (Sandjaja, et al., 2013), meskipun hanya sedikit penelitian yang berfokus pada aspek ini. Rekomendasi terbaru dari WHO (Sari, et al., 2010), memodifikasi klasifikasi sebelumnya anak-anak dan remaja dengan skor $Z$ tinggi untuk usia (HAZ) di kisaran -2 dan -1 dari "ringan kerdil" menjadi "normal". Kemungkinan kekhawatiran sebelumnya tentang ringan kekurangan gizi, yang menjadi dasar dari penelitian sebelumnya, telah agak berkurang karena penurunan di seluruh dunia dalam prevalensi kurang gizi disertai dengan dramatis peningkatan obesitas di antara segmen populasi yang lebih muda.

Namun, penetapan batas yang spesifik dan sensitif poin tetap sangat penting dalam mendeteksi nutrisi disfungsi pada usia dini. Hasil yang diperoleh dalam penelitian ini mengkonfirmasi hipotesis bahwa individu yang agak kerdil memiliki tekanan darah tinggi, dan bahwa kondisi ini diperburuk oleh kelebihan berat badan. Pernyataam ini lebih 
lanjut didukung oleh demonstrasi korelasi yang signifikan antara SBP dan lemak perut dalam kelompok anak-anak dan remaja dengan stunting ringan. Menurut Pedoman (Schmidt, Muslimatun, West, Schultink, Gross, \& Hautvast, 2002), diagnosis hipertensi harus divalidasi dengan tindakan berulang, setidaknya pada tiga kesempatan.

Dalam penelitian ini, rata-rata tiga darah berturut-turut Pengukuran tekanan dilakukan hanya pada satu kesempatan, yang merupakan keterbatasan studi.

Tidak ada perbedaan yang signifikan secara statistik antara anak-anak dan remaja yang mengalami stunting dan normal dengan sehubungan dengan usia, tinggi badan, BMl-untuk-usia persentil dan persentase lemak perut (Tabel 1). Namun, berat ratarata dan BMI nilai-nilai individu yang diklasifikasikan memiliki stunting ringan lebih kecil dari individu normal. Selain itu, sementara 10,9\% individu yang agak kerdil memiliki berat badan kurang (BMI-untuk usia persentil ke-5) dan 16,8\% kelebihan berat badan (BMI-untuk usia persentil ke-85), pada kelompok perawakan normal hanya $4,7 \%$ yang kekurangan berat badan sedangkan 41,4\% kelebihan berat badan. Hasil serupa diperoleh dari analisis di mana individu dengan Stunting ringan dan tekanan darah tinggi dikelompokkan lebih lanjut menurut jenis kelamin dan tahap pubertas.

Studi longitudinal telah menunjukkan bahwa anak-anak dengan peningkatan tekanan darah, termasuk mereka yang bertubuh normal, cenderung mengembangkan hipertensi selama hidup mereka (Semba, De Pee, Hess, Sun, Sari, \& Bloem, 2008). Selain itu, studi seperti sebagai studi Jantung Bogalusa (Toruner \& Savaser, 2010), yang mengevaluasi 116 hipertensi pasien dewasa, mengungkapkan bahwa sebagian besar populasi menunjukkan peningkatan SBP atau DBP selama masa bayi (masingmasing 48\% dan 41\%,). Dengan membandingkan anak-anak dengan normal $(\geq 3,0 \mathrm{~kg})$ dan berat lahir rendah $(\leq 2,5 \mathrm{~kg})$, (Franco et al) menemukan bahwa penurunan berat lahir berkorelasi dengan gangguan endotel dan brakialis fungsi arteri, dan peningkatan SBP selama sepuluh tahun pertama kehidupan. Kelompok anak dengan berat badan lahir rendah disajikan peningkatan kadar asam urat dan penurunan elastisitas pembuluh darah, yang dapat menyebabkan perkembangan penyakit kardiovaskular (CVD).

Selain itu, hubungan antara lemak perut dengan peningkatan nilai SBP ditemukan di antara individu yang terhambat tetapi di antara mereka yang bertubuh tidak normal. Diagnosis dan pengobatan bentuk ringan dari kurang gizi sangat penting untuk meminimalkan/mencegah bahaya konsekuensi di kemudian hari. Mengingat perubahan yang signifikan diamati pada anak-anak yang agak terhambat, disarankan bahwa cutoff point yang diusulkan oleh WHO pada tahun 2007 harus dievaluasi kembali.

Menurut Pantauan Pertumbuhan Usia Sekolah Proyek Anak di Turki, 5\% terhambat dan 21,5\%pendek. Hasil proyek yang sama juga menunjukkan bahwa angka stunting $(5,2 \%)$ dan pendek $(22,3 \%)$ anak perempuan lebih tinggi daripada anak laki-laki (4,9\% dan 20,7\%, masing-masing). Dalam penelitian ini, distribusi skor tinggi $Z$ tidak berbeda berdasarkan jenis kelamin. Dalam sebuah studi yang dilakukan di Irak, tingkat pengerdilan di antara anak-anak usia sekolah usia 7-12 tahun adalah 18,7\% dan stunting adalah yang paling umum $(22,4 \%)$ pada kelompok usia 12 tahun (Branca, Nikogosian, \& 
Lobstain, 2007). Cacat energi keseimbangan akibat kekurangan gizi dini menyebabkan peningkatan adipositas sentral pada anak pendek, oksidasi lemak menjadi lebih rendah, lipolisis dan oksidasi lipid memburuk, dan rasio kortisol terhadap insulin meningkat karena asupan makanan yang tidak mencukupi dan dengan demikian terjadi resistensi insulin.

Tingginya angka stunting dan anak pendek dalam penelitian kelompok patut diperhatikan. Oleh karena itu, pada anak-anak bertekad untuk memiliki pertumbuhan terhambat, deteksi dini dan pemantauan penyakit kronis dengan pemeriksaan fisik rinci adalah penting. Berdasarkan hasil pemeriksaan tekanan darah sistolik, mahasiswa dengan prehipertensi $12,0 \%$, hipertensi derajat I 6,8\%, dan hipertensi derajat II $3,2 \%$. Berdasarkan hasil pemeriksaan tekanan darah diastolik, mahasiswa dengan prehipertensi 10,4\%, hipertensi stadium I 5,5\%, dan hipertensi stadium II $1,1 \%$. Perbedaan antara jenis kelamin tidak signifikan $(p>0,05)$. Menurut pengukuran tekanan darah sistolik dari 1411 anak usia 7-11 tahun, 4,5\% adalah prehipertensi dan $14,3 \%$ adalah hipertensi stadium I (> persentil sembilan puluh lima). Menurut pengukuran tekanan darah diastolik anak-anak tersebut, $4 \%$ adalah prehipertensi dan 4,7\% adalah hipertensi. Dalam penelitian yang dilakukan dengan 402 siswa, 7,5\% memiliki hipertensi stadium II, $12,2 \%$ memiliki hipertensi stadium I, dan 21,9\% memiliki prehipertensi (POKJA, 2004)

Dalam subelemen air, sanitasi, dan lingkungan, satusatunya komponen yang dipelajari dan ditemukan terkait dengan anak pengerdilan adalah urbanisasi, dengan sebagian besar penelitian mengamati bahwa daerah pedesaan memiliki prevalensi stunting anak yang lebih tinggi dibandingkan daerah perkotaan, bahkan miskin daerah perkotaan dan di daerah pedesaan dibandingkan dengan $34,9 \% \quad(95 \% \mathrm{Cl} \quad[32,9,37,0]) \quad \mathrm{di}$ perkotaan daerah, dengan AOR stunting $1,55(95 \% \mathrm{Cl}[1.22,1.97]) \mathrm{di}$ daerah pedesaan versus perkotaan. (Sandjaja, et al., 2013) menganalisis survei cross-sectional dan menemukan perbedaan yang sama dalam prevalensi stunting di kelompok usia yang sama-pedesaan 47,3\% dan perkotaan 28,5\%. (Semba, De Pee, Hess, Sun, Sari, \& Bloem, 2008)menemukan bahwa kemungkinan stunting pada anak 0 59 bulan cukup tinggi di pedesaan versus perkotaan, (AOR 1,136, 95\% Cl [1.075, 1.202]). Satu studi melaporkan bahwa kemungkinannya stunting lebih tinggi di perkotaan dibandingkan dengan perdesaan di anak-anak 0-59 bulan (UOR 1,33, 95\% $\mathrm{Cl}[1,03,1,71])$, tapi itu sebuah studi cross-sectional yang dilakukan hanya di provinsi Maluku Utara, dan $95 \% \mathrm{Cl}$ untuk perkiraan prevalensi pengerdilan di daerah pedesaan masih tinggi (Chinn \& Rona, 2001).

Faktor masyarakat yang tidak dinilai terkait dengan stunting atau pertumbuhan linier anak di Indonesia meliputi ketersediaan pasokan kesehatan, infrastruktur dan layanan air dan sanitasi, kepadatan penduduk, perubahan iklim, harga pangan dan kebijakan perdagangan, peraturan pemasaran, stabilitas politik, jasa keuangan, dan semua determinan dalam subelemen pendidikan, masyarakat dan budaya, dan sistem pertanian dan pangan.

Dalam penelitian lain, 1,30\% memiliki hipertensi presistolik, 2,02\% memiliki hipertensi sistolik, 2,65\% memiliki hipertensi prediastolik, dan 2,74\% memiliki hipertensi diastolik. Distribusi tekanan darah pada skrining awal adalah sebagai berikut: normal 
$(81,1 \%)$, prehipertensi $(9,5 \%)$, dan hipertensi $(9,4 \%)$ (stadium I, 8,4\%, stadium II, 1\%) (Sari, et al., 2010). Prevalensi total hipertensi pada anak usia 6-18 tahun di India adalah 6,48\% (674\% pada anak laki-laki dan 6,13\% pada anak perempuan), dan prevalensi hipertensi meningkat seiring bertambahnya usia pada kedua jenis kelamin. Dalam penelitian lain, total prevalensi hipertensi pada anak sekolah usia 515 tahun adalah 3,19\% (3,16\% pada anak perempuan dan 3,22\% pada anak laki-laki) (POKJA, 2004). Dalam studi yang dilakukan di Turki, prevalensi berkisar antara 3,8\% dan 17,8\% (Pekcan, Penetapan Status Gizi Seri Informasi Gizi Pelayanan Kesehatan Dasar Managemen Umum Kementrian Kesehatan Republik Turki, 2008b). Hasil penelitian ini lebih rendah dari beberapa penelitian dan lebih tinggi dari beberapa penelitian lain. Rentang luas prevalensi hipertensi mungkin disebabkan oleh perbedaan antara teknik pengukuran dan penilaian yang digunakan dalam studi dan kebiasaan makan serta karakteristik demografi anak-anak.

Kerangka konseptual WHO memungkinkan tinjauan menyeluruh dari literatur determinan stunting anak di Indonesia. Hasil penelitian ini menunjukkan adanya bukti yang kuat dan konsisten dari hasil pengujian dan studi observasional bahwa faktor tingginya tekanan darah pada anak merupakan ha yang penting sebagai faktor penentu stunting anak di Indonesia. Barubaru ini. Pada akhir-akhir ini, studi cross-sectional menyarankan penghentian menyusuidini, perawakan ayah, dan rumah tangga dengan air minum yang tidak diolah dan jamban yang tidak baik juga dapat menjadi penentu kuat anak stunting di Indonesia, tetapi penelitian lebih lanjut diperlukan untuk mengkonfirmasi hal ini.

\section{KESIMPULAN}

Hasil penelitian ini menunjukkan bahwa prevalensi stunting, sedikit kelebihan berat badan/over berat badan, hipertensi stadium I dan hipertensi stadium II pada anak usia 5-14 tahun tergolong tinggi. Oleh karena itu, rutinitas pemutaran di sekolah memegang peran penting dalam mengatasi masalah, seperti stunting, hipertensi, dan sedikit kelebihan berat badan / kelebihan berat badan di antara anak-anak. Khususnya program pencegahan dan penanggulangan-penanggulangan obesitas serta penerapan pola makan sehat kebiasaan dan aktivitas fisik akan berkontribusi pada pembuktian pningkatan kesehatan. Pelaksanaan dan pengawasan dari program ramah gizi di semua sekolah akan efektif dalam memerangi obesitas dan hipertensi.

Perawat kesehatan sekolah diketahui memiliki berbagai peran dan tanggung jawab penyelenggaraan kesehatan program perlindungan dan promosi yang bertujuan untuk melindungi dan meningkatkan kesehatan di dunia khususnya di Indonesia untuk diperhatikan lebih baik lagi dan diterapkan oleh sekolah perawat kesehatan. Bukti di Indonesia terutama sejalan dengan proksimat umum penyebab stunting anak diidentifikasi dalam literatur yang lebih luas adalah hipertensi yang juga dipacu oleh kadar darah pada ibu yang tinggi dan pendidikan, kelahiran prematur dan panjang lahir, eksklusif menyusui selama 6 bulan, dan status sosial ekonomi rumah tangga.

Tidak mengherankan, air minum bersih sangat penting bagi rumah tangga dengan jamban yang layak. Dengan begitu, hal ini berpotensi menurunkan angka kejadian stunting anak, khususnya di wilayah pedesaan Indonesia, kemungkinan karena penyediaan zat gizi mikro dan zat 
gizi makro selama periode pertumbuhan kritis awal ketika makanan pendamping pertama kali diperkenalkan.

Beberapa determinan terdekat diidentifikasi dalam Kerangka kerja WHO belum dinilai dampaknya terhadap anak stunting di Indonesia, dan studi yang mengatasi kesenjangan pengetahuan ini di Indonesia sangat dibutuhkan. Faktor masyarakat dan masyarakat jugavital - terutama menangani kesehatan dan perawatan kesehatan - tetapi lebih banyak penelitian diperlukan untuk mengatasi jalur antara ekonomi politik, pendidikan, masyarakat dan budaya, sistem pertanian dan pangan, dan air, sanitasi, dan lingkungan dan pengerdilan anak, yang kemungkinan memegang peranan penting di Indonesia.

\section{DAFTAR PUSTAKA}

Agca, \& Koncoglu, G. (2010). Efek Olah Raga Teratur Pada Komposisi Tubuh Pada Remaja Putri yang Kelebihan Berat Badan dan Obesitas. Jurnal Kedokteran , 85: 17-23.

Aonallah, Skhiri, H., El, A. J., Traissack, P., Ben, R. H., Eimart, et al. (2012). Faktor Terkait Tekanan Darah pada Populasi Pemuda Afrika Utara. Lintas Sektoral Belajar di Tunisia. Jurnal Kesehatan Masyarakat BMC , 12 : 98.

Branca, F., Nikogosian, H., \& Lobstain, T. (2007). Tantangan dan Strategi WHO Untuk Respon Obesitas di Wilayah Eropa. Denmart: Kantor Regional WHO untuk Eropa.

Chinn, S., \& Rona, R. (2001). Prevalensi dan Kelebihan Berat Badan dan Obesitas Dalam Tiga Study Cross Sectional Anak-anak Inggris. BMJ , 332:24-6.

Discigil, G., Aydogdu, A., Basak, O., Gemalmaz, A., \& Gurel, S.
(2007). Prevalensi Hipertensi dan Faktor Terkait Pda Siswa Sekolah Dasar di Aydan. TJFMPC , $12: 17-22$.

Ergun, A., Erol, S., Gur, K., \& Isman, F. (2016). Evaluasi Kesehatan Pengembangan Anak Usia Sekolah. Ankara.

Evaluasi, Diagnosa danPengobatan Tekanan Darah Tinggi Pada Anak Dan Remaja. (2005). Departemen A.S of Healtd And Human Services National Institutes of Health National Heart, Lung, And Blood Istitute.

Kilic, Z., Basibuyuk, T., Tekin, N., Nalir, A., \& Olak. (1995). Faktor Resiko pada Anak dengan Orang Tua Hipertensi Esensial. Jurnal Fakultas Kedokteran Universitas Osmangazi , 17: 49-57.

Nihiser, A., Lee, S., Wechsler, H., McKenna, M., Odom, E., \& Reinold, C. d. (2007). Pengukuran Indeks Masa Tubuh Disekolah. Jurnal Kesehatan , 77 :651-657.

Pekcan, G. (2008a). Penentuan Status Gizi Diet Handbook. In A. V. Baysal. Ankara Penerbit Hatipoglu.

Pekcan, G. (2008b). Penetapan Status Gizi Seri Informasi Gizi Pelayanan Kesehatan Dasar Managemen Umum Kementrian Kesehatan Republik Turki. Ankara Tipografi Klasmat.

POKJA. (2004). Program Pendidikan Tekanan Darah Tinggi Nasional Tentang Pengendalian Hipertensi Pada Anak dan Remaja. Laporan Keempat pada Diagnosis, Evaluasi dan Pengobatan Tekanan Darah Tinggi di Anak-anak dan Remaja. Pediatri , 114:555-73.

Sandjaja, S., Budiman, B., Harahap, H., Ernawati, F., Sukatri, M., Widodo, Y., et al. (2013). Food indnesia Children Consumption and Nutritional and Biochemical Status of 0.5-12 Year old. The 
SEANUTS study. Brritish Journal Of Nutrition , 110 (S3), S11-S20. Sari, M., de Pee, S., Bloom, M. W., Sun, K., Thorne-Lyman, A. L., Moenc-Pfanner, R., et al. (2010). Higher Household Expnditure On Animl-Source And Nongrain Foods Lowers The Risk Of Stunting Among Chlidren 0-59 Months old in Indonesia : Implikations of Rissing Food Prices. The Jurnal Of Nutrition , 140(1) 195S-200S.

Schmidt, M. K., Muslimatun, S., West, C. E., Schultink, W., Gross, R., \& Hautvast, J. G. (2002). Nutritional Status And Linier Grownt of Indonesian Infants In West Java Are Determined More By Prenatal Environment Than By Prostnatal Facktors. The Journal of Nutrition , 132(8), 2202-2207.

Semba, R. D., De Pee, S., Hess, S. Y., Sun, K., Sari, M., \& Bloem, M. W. (2008). Child Malnutrition and Mortality Among Families Not Utilizing Adequately lodized Salt In Indonesia. The American Journal of Clinial Nutrition, 87(2), 438-444.

Shi, Y., Groh, M., \& Morrison, H. (2012). Meningkatkan Tekanan Darah dan Hunungannya Faktor Pada Anak-anak dan Remaja Kanada dari Survei Tindakan Kesehatan Kanada. Jurnal Kesehatan masyarakat BMC , 12 : 388.
SIAPA. (2007b). Data Referensi Pertumbuhan Selama 5-19 Tahun. Retrieved September 10, 2020, from www.siapa.int/chilgrouwth/id/

Toruner, E., \& Savaser, S. (2010). Evaluasi Terkontrol Berbasis Sekolah Pencegahan Obesitas Pada Anak Sekolah Di Turki. Jurnal Sch Nurs , 26:473-82.

Tumer, N., Yalcinkaya, F., Nce, E., Ekim, M., Kose, K., Akar, N., et al. (1999). Program Tekanan Darah untu Anak-anak dan Remaja di Turki. Turki: Anak Nefrol.

Yuce, H. (2007). Skrinning Obesitas dan Hipertensi Sebagai Fakror Resiko Metabolik Faktor Resiko Sindrom pada Anak Sekolah. Penelitian Isli Etfal Departemen Kesehatan. Tesis Spesialis , 4757. 